\section{Políticas públicas educacionais. Maria José Aviz do Rosário e Ronaldo Marcos de Lima Araújo (Orgs.). Campinas: Alínea, 2008, 156 p.}

Eliza Bartolozzi Ferreira

Universidade Federal do Espírito Santo, Espírito Santo, Brasil

<eliza.bartolozzi@gmail.com>

Este livro é resultado de estudos e pesquisas empreendidos no interior do Programa de PósGraduação em Educação/Centro de Educação/ Universidade do Pará. É relevante a contribuição desta obra no conjunto da produção científica que estuda as políticas educacionais implantadas no último quartel do século XX e início do século XXI. As transformações políticas, econômicas e culturais resultantes do processo de globalização tiveram um impacto significativo na organização da educação brasileira, o que motivou uma produção relativamente extensa de conhecimento sobre as políticas educacionais, reunindo uma considerável contribuição para o pensamento e a prática educacional no país. Este livro se insere nesse quadro.

Em uma perspectiva teórica crítica, esta obra oferece um panorama das políticas públicas educacionais da atualidade, utilizando-se de diversos recursos metodológicos como estratégia de análise do objeto em questão, tais como: a historiografia para o estudo da organização escolar em Belém e para o debate da exclusão e elitização da escola brasileira; a hermenêutica como recurso para a compreensão do trabalho como princípio educativo, tema importante para os educadores, principalmente, devido à atual implantação da política de Ensino Médio integrado; e o estudo de caso, para a reflexão da formação de docentes na educação profissional no bojo das políticas do Programa de Educação de Jovens e Adultos (Proeja) e do Programa Nacional de Inclusão de Jovens (Projovem), no Pará. Além disso, o livro conta com estudos sobre a política de avaliação institucional do Ensino Superior e sobre o caráter da política de autonomia escolar desenvolvida no quadro da reforma do Estado brasileiro.

"Se o trabalho foi sempre um fato educativo, em que sentido Marx pode ser considerado o fundador da pedagogia que elege o trabalho como seu princípio educativo fundamental?"
Com essa pergunta, tem início o capítulo 1 do livro, sob o título "O trabalho como princípio pedagógico em Marx, Lênin e Gramsci e sua problemática na atualidade". O texto é uma produção conjunta de Paolo Nosella e Elinilze Guedes Teodoro, os quais se utilizam do método hermenêutico ou histórico-filológico, pois o objetivo é o estudo de textos a partir dos sentidos das palavras escritas em seu contexto original. Os autores tiveram como preocupação mostrar que a originalidade de Marx consistiu em transformar o fato universal em princípio teórico. Para comprovar essa assertiva, eles se pautaram na conhecida obra de Mario Alighiero Manacorda, Marx e a pedagogia moderna, que resgata os escritos de Marx, Lênin e Gramsci. Algumas clássicas teses marxistas são destacadas no texto: o trabalho é historicamente determinado e ligado à educação; uma nova sociedade deve unir o ensino ao trabalho produtivo das jovens gerações; uma escola politécnica suprime a divisão do trabalho entre os homens e entende que a relação entre escola e trabalho produtivo inscreve-se numa concepção de cultura desinteressada, de longo alcance cientifico, humanística e moderna. Esta problemática, posta na realidade contemporânea do pós-industrialismo, é aprofundada porque implica na superação das graves condições sociais.

O capítulo 2, "Formação de docentes para a educação profissional e tecnológica: por uma pedagogia integradora da educação profissional", escrito por Ronaldo Marcos Lima de Araújo, objetiva refletir sobre a formação de docentes na educação profissional, a partir das experiências de pesquisa desenvolvidas no âmbito do Proeja e do Projovem. O autor resgata os conhecimentos produzidos pela didática e adota o materialismo histórico como referência teórica. Seu estudo afirma sobre a necessidade de uma didática para a formação do docente da educação profissional, que deve incluir a articulação dos saberes técnicos específicos da área, dos saberes didáticos e do saber do pesquisador. Essa formação, segundo o autor, deve ser feita nas universidades e nos centros de educação tecnológica - atualmente, Instituições Federais de Ensino Superior (Ifes). Não obstante salientar a importância do Proeja e do Projovem como política social, o autor destaca as dificuldades desses programas no que diz respeito à sua execução, pelo fato de o quadro docente 
não atender aos referenciais teóricos necessários de formação em uma educação profissional comprometida com a emancipação do trabalhador.

O capítulo 3, “A organização do ensino público primário de Belém-PA - 1930/1937: projeto político-educacional", de Maria José Aviz do Rosário, busca compreender as raízes da organização escolar em Belém ao resgatar o movimento político do período varguista de 1930 a 1937. Nessa época sob o domínio de interventores políticos com perfil coronelista, o município de Belém tinha uma rede de ensino relativamente grande, em que pesava a ausência de uma autonomia política e financeira. O projeto político-educacional empreendido em Belém, no período em questão, é revelado pela autora a partir da análise de documentos primários que registram a opção dos interventores pela modernização do ensino à moda da escola ativa. Nesse passo, a organização escolar do município de Belém seguiu as orientações do escolanovismo como estratégia de acomodação da correlação de forças políticas da época.

Com a discussão sobre a importância, complexidade e ambiguidade presentes na correlação de forças políticas na sociedade contemporânea, a autonomia da escola é posta em questão no capítulo 4. Com o título "Autonomia da escola pública: diferentes concepções em embate no cenário educacional brasileiro", Antonio Cabral Neto e Luis Carlos Marques Sousa traçam uma análise crítica do contexto histórico vivido no Brasil após a década de 1990, conhecido pela adoção de políticas neoliberais, com o objetivo de identificar suas implicações na ressignificação do conceito e da prática da autonomia nas escolas públicas do país. Segundo os autores, a apropriação indevida do conceito de autonomia empreendida pelas políticas educacionais das duas últimas décadas dificulta o processo de democratização da gestão educacional, pois sua ênfase se dá na desconcentração de responsabilidades para as unidades escolares, sem a devida descentralização do processo de tomada de decisão. Essa tendência segue o caminho oposto das lutas dos educadores iniciadas no movimento histórico ensejado pelos pioneiros da educação nova.

A política de avaliação do Ensino Superior é o tema abordado no capítulo 5, "A avaliação institucional como política pública", escrito por Olgaíses Maués, com ênfase na análise do
Sistema Nacional de Avaliação da Educação Superior (Sinaes). A autora faz uma reflexão crítica do contexto de regulação implantado no processo de reforma do Estado brasileiro após a década de 1990, no qual a avaliação institucional é alçada como uma estratégia de controle e de formalização da lógica privatista dominante no mundo ocidental. A reforma do Estado pode ser caracterizada como estratégia de implantação de um Estado regulador e avaliador. O conceito de regulação é desenvolvido pela autora como formas que o Estado busca para exercer seu controle sobre a sociedade. Para tanto, o gerencialismo é uma estratégia utilizada no lugar do modelo burocrático dominante na maioria dos Estados capitalistas. Nesse modelo, o Estado deixa de controlar o processo e passa a centrar seu interesse apenas nos resultados e, com isso, adota práticas mais flexíveis na definição dos processos e uma maior rigidez na avaliação da eficiência e eficácia dos resultados. A nova regulação, portanto, tem como objetivo a realização de um ajuste de acordo com o mercado, mediante a desconcentração das ações. A autora ressalta que a avaliação institucional deveria assumir uma concepção progressista, tal como defendida pelos movimentos organizados, sendo aquela referenciada nas demandas da sociedade e responsabilizada em acompanhar todo o processo institucional ao permitir o ajuste de percurso com a finalidade de cumprir as metas sociais de uma qualidade emancipatória. Ao centrar a análise no Sinaes, a autora destaca sua congruência com a concepção de regulação hegemônica, pois apresenta caráter somativo e punitivo, distante da proposta inicialmente elaborada pelo governo atual.

O capítulo 6 é uma produção conjunta de Amarílio Ferreira Jr. e Marisa Bittar, intitulado "Elitismo e exclusão na educação brasileira". Ao passo que a exclusão da escolaridade, para a maioria da população brasileira, foi arquitetada pela classe dominante, a educação foi considerada um privilégio dos poucos que constituíam a elite nacional. Os autores defendem que a sociedade brasileira, até o início da década de 1970, era uma "sociedade sem escolas", não obstante o país sempre ter contado com a existência da instituição escolar. Os argumentos dos autores são construídos com base na historiografia da educação brasileira, cujo movimento se inicia no período colonial. Neste, o ensino 
era protagonizado pelos jesuítas, pautado pela aquisição do saber clássico acumulado pela civilização ocidental cristã. Era um ensino altamente refinado e eficiente para os fins sociais e culturais do poder hegemônico. Com a expulsão dos jesuítas do Brasil, os autores resgatam as reformas pombalinas, as quais transferiram a educação quase que exclusivamente a cargo das famílias pertencentes à aristocracia agrária escravocrata. Com o advento da República, o traço elitista permaneceu. Foi somente na ditadura militar que a expansão do ensino tornou-se uma realidade ou, nas palavras dos autores, "que a sociedade brasileira deixou, na realidade, de ser uma 'sociedade sem escolas'". Todavia, o traço característico da constituição da educação brasileira é a sua dualidade: escolas de ensino precário para as classes populares e escolas eficientes para as elites. 